\title{
Mercury methylation in oxic aquatic macro-environments: a review
}

\author{
Andrea Gallorini*, Jean-Luc Loizeau \\ Department F.-A. Forel for Environmental and Aquatic Sciences, and Institute for Environmental Sciences, University of Geneva, \\ Boulevard Carl-Vogt 66, 1205 Geneva, Switzerland
}

\begin{abstract}
Mercury methylation in aquatic environments is a key process that incorporates this neurotoxin into the food chain and ultimately the human diet. Mercury methylation is considered to be essentially biotic and mainly driven by sulfate-reducing bacteria present in the bottom sediments in aquatic systems. However, in recent decades, many researchers have shown that this methylation also occurs in oxic layers in conjunction with a high content of particulate organic matter and localized depletion of dissolved oxygen. The goals of this review are to summarize our current understanding of $\mathrm{Hg}$ methylation in water columns of both marine and freshwater environments, as well as to highlight knowledge gaps and future research needs. Most of the literature showed that suspended particles (known as marine and lake snow) could be the microenvironment in which $\mathrm{Hg}$ methylation could occur across oxic water columns, because they have been recognized as a site of organic matter mineralization and as presenting oxygen gradients around and inside them. To date, the majority of these studies concern marine environments, highlighting the need for more studies in freshwater environments, particularly lacustrine systems. Investigating this new methylmercury production environment is essential for a better understanding of methylmercury incorporation into the trophic chain. In this review, we also propose a model that attempts to highlight the relative importance of a $\mathrm{MeHg}$ epilimnetic path over a $\mathrm{MeHg}$ benthic-hypolimnetic path, especially in deep lakes. We believe that this model could help to better focus future scientific efforts in limnic environments regarding the $\mathrm{MeHg}$ cycle.
\end{abstract}

\section{INTRODUCTION}

Mercury is one of the most hazardous trace elements in the environment because of its neurotoxicity and its ability to bioaccumulate and biomagnify in food webs, under its methylated form $\mathrm{CH}_{3} \mathrm{Hg}^{+}$(monomethylmercury, $\mathrm{MMHg}$ ), which poses a direct threat to humans and wildlife (Amap/Unep, 2013, 2015).

In an attempt to assess how the expected $\mathrm{Hg}$ emission reduction - following the entry into force of the Minamata Convention - will reflect on $\mathrm{Hg}$ concentrations in the human food chain, Wang et al. (2019) investigated the $\mathrm{Hg}$ concentrations in biota from an oceanic dataset. They found that in most cases, the evolution of $\mathrm{Hg}$ concentration in biota did not follow $\mathrm{Hg}$ atmospheric deposition

Corresponding author: andrea.gallorini@unige.ch

Key words: Methylmercury; hgcAB gene cluster; $\mathrm{Hg}$ methylation in freshwater; $\mathrm{Hg}$ methylation in marine water; lake and marine snow.

Edited by: Diego Fontaneto, CNR-IRSA, Verbania, Italy.

Received: 26 January 2021.

Accepted: 27 February 2021.

This work is licensed under a Creative Commons Attribution NonCommercial 4.0 License (CC BY-NC 4.0).

${ }^{\circ}$ Copyright: the Author(s), 2021

Licensee PAGEPress, Italy

J. Limnol., 2021; 80(2):2007

DOI: 10.4081/jlimnol.2021.2007 trends, with a divergence more evident in the last two decades. Two factors appear to be at the origin of this lack of correlation: i) the Hg legacy present in aquatic environments, which allows $\mathrm{Hg}$ to remain bioavailable for a very long time; and ii) local processes are responsible for $\mathrm{Hg}$ speciation conversion and, in turn, its bioavailability. Together, they produce a substantial lag in the response of $\mathrm{Hg}$ in biota to external $\mathrm{Hg}$ input (e.g., atmospheric emission and deposition). This evidence highlights the importance of $\mathrm{Hg}$ legacy in aquatic systems over the expected decrease of new $\mathrm{Hg}$ emissions into the atmosphere (Selin, 2014). The Minamata Convention may only have long-term effects; legacy $\mathrm{Hg}$ pollution present in the environment could affect humans and wildlife for centuries to millennia because of the long timescales of mercury cycling (Sunderland and Selin, 2013).

The organic forms of mercury [MMHg and dimethylmercury (DMHg)] are usually not released into the environment, but are produced in aquatic environments, mostly by biological processes taking place in a variety of settings, such as bottom sediments, flooded soils, wetlands, oxygen deficient zones of water columns, and settling particles (Ullrich et al., 2001; Benoit et al., 2003; Bravo and Cosio, 2019), and carried out by a variety of microorganisms (Pak and Bartha, 1998; Paranjape and Hall, 2017; Regnell and Watras, 2019).

Despite the importance of sediments in the production of MeHg, several studies (Topping and Davies, 1981; Mason and Fitzgerald, 1990; Eckley and Hintelmann, 2006; Monperrus et al., 2007a, 2007b; Cossa et al., 2009; Lehnherr et al., 2011; Gascón Díez et al., 2016; Soerensen et al., 2018) have shown that a non-negligible fraction of $\mathrm{Hg}$ is methylated within the water column of both marine 
and freshwater systems, environmental compartments in which this transformation has been underestimated so far.

Growing evidence shows that conditions for the methylation of mercury could exist inside and around micro- and macroaggregates in the water column under both oxic and anoxic conditions (Alldredge and Cohen, 1987; Glud et al., 2015). The marine and estuarine aggregates known as "marine snow" are the most studied so far; however, the scientific focus is slowly turning toward lake environments and "lake snow" (Ortiz et al., 2015; Paranjape and Hall, 2017).

Fish consumption is the primary pathway for human exposure to $\mathrm{MeHg}$, which is a major health concern (Fitzgerald and Lamborg, 2014). Of the global fish production in 2016, 90.9 million tons came from captured wildlife and a non-negligible part of it (12.8\%) is represented by freshwater fish (Fao, 2018). The presence of a $\mathrm{MeHg}$ production zone in the oxic layers of limnic environments is likely to increase the $\mathrm{MeHg}$ uptake by phytoand zooplankton, which represent the base of the trophic chain, and in turn, $\mathrm{MeHg}$ becomes available to higher trophic-level organisms.

This endogenic source (production within the water column) of $\mathrm{MeHg}$ is an entry point into the trophic chain that may be particularly important in deep lakes because of the great distance between the surface water and the sediments. Using a conceptual transport model, we highlighted the relative importance between the transfer paths created by the presence of these two sources of $\mathrm{MeHg}$ (i.e., bottom sediments and settling particles), underlining their effect on the biota $\mathrm{MeHg}$ uptake.

\section{MERCURY METHYLATION AND DEMETHYLATION IN AQUATIC SYSTEMS}

Mercury methylation in aquatic environments is recognized to be mainly related to a biological pathway, in particular to the activity of sulfate-reducing bacteria (SRB) belonging to the class of $\delta$-proteobacteria (Compeau and Bartha, 1985; King et al., 2000). Other bacteria are known to play roles in the methylation process, including some strains of methanogens (Parks et al., 2013; Podar et al., 2015), iron-reducing bacteria (Fleming et al., 2006; Si et al., 2015; Correia and Guimarães, 2017; Bravo et al., 2018), and Firmicutes (Gilmour et al., 2013). A particular gene cluster that is proposed to be essential for $\mathrm{Hg}$ methylation has been found in every known methylator. The two-gene cluster $h g c A B$ is currently the primary indicator used to detect bacteria capable of methylation (Schaefer et al., 2011; Parks et al., 2013; Podar et al., 2015; Bravo and Cosio, 2019; Regnell and Watras, 2019). Peterson et al. (2020) investigated an anoxic sulfidic hypolimnion lake with shotgun metagenomics to determine the presence of the gene cluster $h g c A B$ in the microorgan- ism's population. Surprisingly they found that the wellstudied sulfate-reducing bacteria only account for the $22 \%$ of all the genome coverage, whereas fermenters were the most abundant accounting for more than half of the genome coverage.

The reason why microbes methylate $\mathrm{Hg}$ is still unclear. Methylation of $\mathrm{Hg}$ facilitates the detoxification of the cell (Regnell and Watras, 2019); however no strong correlation between the concentrations of $\mathrm{Hg}$ and $\mathrm{MeHg}$ and presence of the $h g c A B$ gene cluster has been found (Christensen et al., 2019; Regnell and Watras, 2019), in contrast to the mer operon which is a multi-proteins detoxification systems in which clustered genes in an operon produce the proteins needed to reduce $\mathrm{Hg}^{2+}$ to volatile $\mathrm{Hg}^{0}$ and expel it from the cell (Nascimento and Chartone-Souza, 2003). This evidence could imply that while $h g c A B$ is used by cells to remove $\mathrm{Hg}$, the primary function of these genes may not be $\mathrm{Hg}$ detoxification but could be related to one-carbon metabolism and metal homeostasis, as suggested by Qian et $a l$. (2018). Additionally, the $h g c A B$ gene cluster is not essential for the survival of the microorganisms in the environment (Parks et al., 2013).

The methylation rate depends mainly on two parameters: the concentration of bioavailable $\mathrm{Hg}$ and the activity of methylating bacteria. Microbial populations need specific conditions to live and subsequently to produce $\mathrm{MeHg}$. Several parameters have to be taken into account when assessing the productivity of a bacterial population, such as temperature, $\mathrm{pH}$, redox potential, organic matter (OM), and sulfide (Paranjape and Hall, 2017; Bravo and Cosio, 2019).

In contrast, both biotic and abiotic degradations of $\mathrm{MeHg}$ are important processes in natural systems that regulate the concentration of $\mathrm{MeHg}$ in sediments and waters. Demethylation in natural environments occurs through biotic (mediated by numerous strains of aerobes and anaerobes) (Zhang and Planas, 1994; Matilainen and Verta, 1995; Lu et al., 2016; Lu et al., 2017; Paranjape and Hall, 2017) and abiotic processes such as photodegradation of $\mathrm{MeHg}$, which is considered to be the main process of abiotic demethylation, and chemical degradation of $\mathrm{MeHg}$, which is linked mainly to the selenoamino assisted degradation (Paranjape and Hall, 2017; Du et al., 2019).

\section{MERCURY METHYLATION IN THE WATER COLUMN}

All known microorganisms carrying the $h g c A B$ gene cluster are obligate anaerobes (Gilmour et al., 2013), an observation that suggests an incompatibility between $\mathrm{Hg}$ methylation and water columns (where anoxic conditions are rare), limiting the $\mathrm{MeHg}$ production zone of aquatic systems to anoxic bottom sediments. Early studies (Topping and Davies, 1981; Mason and Fitzgerald, 1990) 
showed the presence of $\mathrm{MeHg}$ in the marine water column. Many other studies - discussed in the next paragraph - have confirmed these findings both in marine and freshwater water columns. This apparent paradox has three possible explanations: i) the presence of anoxic microenvironments along the water column that can sustain $\mathrm{Hg}$ methylation by obligate anaerobes; ii) different pathways for $\mathrm{Hg}$ methylation beside the $h g c A B$ pathway; and iii) the presence of the $h g c A B$ methylation pathway inside microorganisms that are not obligate anaerobes (Bowman et al., 2019). The last two hypotheses remain to be tested, although some indications in their favor already exist. Gionfriddo et al. (2016) identified the microaerophilic bacterium Nitrospina as a potential methylator in Antarctic sea ice, which was supported by Villar et al. (2020) who identified Nitrospina as a likely key player in Hg methylation in the oxic subsurface of all oceans. Podar et al. (2015) found little to no evidence for the presence of the $h g c A B$ gene cluster in the pelagic marine water column; interestingly, they found $h g c A$-like sequences in several metagenomes from the mesopelagic equatorial Pacific Ocean and the Southern Atlantic Ocean, which were also identified in Artic seawater by Bowman et al. (2019). Using polymerase chain reaction amplification and shotgun metagenomics, they did not find $h g c A B$ in the Artic water column; instead, they identified Hg-cycling genes from the mer operon and $h g c A$-like paralogs. Munson et al. (2018) proposed that non-cellular or extracellular methylation and demethylation mechanisms, such as $\mathrm{Hg}$ ligands, competing metals and particle-driven demethylation, could be of major importance in understanding the concentrations of $\mathrm{MeHg}$ in oligotrophic marine waters.

The hypothesis of a specific microenvironment in which $\mathrm{Hg}$ methylation could occur along the water column is supported by an increasing number of reports in both marine (Monperrus et al., 2007a; Monperrus et al., 2007b; Cossa et al., 2011; Lehnherr et al., 2011; Wang et al., 2012; Blum et al., 2013; Lamborg et al., 2016; Bianchi et al., 2018) and freshwater environments (Eckley and Hintelmann, 2006; Gascón Díez et al., 2016). As the literature agrees that particulate organic carbon (POC) is the main candidate for this ecological niche of methylating obligate anaerobes, we present a comprehensive review of the role of $\mathrm{POC}$ in $\mathrm{Hg}$ methylation in the following paragraphs.

\section{Evidence from macro-environment observations}

Evidence for the presence $\mathrm{MeHg}$ in oceanic water columns has been collected by several authors from every ocean and the Mediterranean Sea (Topping and Davies, 1981; Mason and Fitzgerald, 1990; Mason and Fitzgerald, 1993; Kirk et al., 2008; Cossa et al., 2009; Sunderland et al., 2009; Cossa et al., 2011; Lehnherr et al., 2011; Wang et al., 2012; Bowman et al., 2015; Bowman et al., 2016;
Cossa et al., 2018; Wang et al., 2018), except for the Indian Ocean, which remains untested. The vast majority of the literature agrees on the importance of remineralization of $\mathrm{OM}$ in driving $\mathrm{Hg}$ methylation along water columns. Many pieces of evidence were collected and experiments have been carried out to test this hypothesis, e.g., Monperrus et al. (2007a, 2007b) conducted experiments in the marine and coastal waters of the Mediterranean Sea. They carried out several incubation experiments using isotopically enriched spikes of $\mathrm{Hg}$ and $\mathrm{MeHg}$ species $\left({ }^{199} \mathrm{Hg}[\mathrm{II}]\right.$ and $\mathrm{Me}^{201} \mathrm{Hg}$ ) to assess the relative importance of photochemical versus biological processes in $\mathrm{Hg}$ transformation mechanisms. Their results show that $\mathrm{Hg}$ methylation takes place in the oxic surface seawater, especially in the lower euphotic zone where the photochemical processes (i.e., photodemethylation) are attenuated and the biomass concentration is at a maximum.

Similarly, Lehnherr et al. (2011) conducted several incubations in polar marine water, with samples from across the Canadian Artic Archipelago. They reported Hg methylation in the oxic waters that was strongly related to POC abundance and microbial decomposition.

Cossa et al. (2009) produced a high-resolution vertical profile of MeHg concentrations in the Mediterranean Sea. Their results showed, for the first time, that within the most biologically active zone, the $\mathrm{MeHg}$ vertical profile followed a nutrient-like pattern. Following this evidence, the authors suggest that the in situ methylation of inorganic $\mathrm{Hg}$ is associated with the mineralization of OM.

Cossa et al. (2011) found some of the highest concentrations of MeHg among open ocean waters in Antarctic waters. They found that $\mathrm{MeHg}$ concentrations increased with depth at the 27 stations located between Tasmania and Antarctica. They suggested that Hg methylation results from phytoplankton blooms, which produce particles able to scavenge $\mathrm{Hg}$ from the subsurface waters and are subsequently used as substrate for methylating microorganisms in hypoxic zones along the water column. The link between the oxygen depleted zone (ODZ) and mineralization of $\mathrm{OM}$ as the main parameters that promote $\mathrm{Hg}$ methylation in marine water columns has been suggested by several authors in other parts of the world (Lamborg et al., 2008; Wang et al., 2012; Blum et al., 2013; Bowman et al., 2015; Bowman et al., 2016; Lamborg et al., 2016; Cossa et al., 2017; Kim et al., 2017; Cossa et al., 2018; Soerensen et al., 2018). Recently, Soerensen et al. (2018) found $\mathrm{MeHg}$ in hypoxic and anoxic waters at 2-6 and 30-55 times higher concentrations than in oxic water in the Baltic Sea, respectively. Their results suggest that concentrations of elemental $\mathrm{Hg}$ can be associated with redox conditions in the water column and are linked to the cycles of Fe and S, which in turn cause a highly dynamic speciation and bioavailability of $\mathrm{Hg}$ in the hypoxic zone. While phytoplankton mostly thrive in the oxic zone, 
Soerensen et al. (2018) also found that zooplankton are exposed to two to six times higher $\mathrm{MeHg}$ concentrations in hypoxic than in oxic water during summer, creating a dangerous input of $\mathrm{MeHg}$ into the food chain.

In contrast, other authors suggest that only the bacterial decomposition of POC has a real impact on $\mathrm{Hg}$ methylation in the marine water column. Malcolm et al. (2010) found no evidence correlating the oceanic oxygen deficient zone with increased $\mathrm{Hg}$ methylation, but did observe a strong link with the rate of biological decomposition of OM, an observation supported by the work of Sunderland et al. (2009) who found decreasing $\mathrm{MeHg}$ concentrations with increasing apparent oxygen utilization in the Eastern North Pacific. Moreover, Lamborg et al. (2008) showed that the highest $\mathrm{MeHg}$ concentration in the Black Sea was recorded at the top of the low oxygen zone, in contrast with the study of Rosati et al. (2018), which identified the maximum MeHg peak in the permanently anoxic water of the Black Sea, suggesting that this layer is the major source of $\mathrm{MeHg}$ for the entire basin.

Eckley and Hintelmann (2006) found increasing concentrations of $\mathrm{MeHg}$ along the water column of several Canadian lakes, where the seasonal variations in the oxycline create anoxic conditions. Their data showed a doubling of the concentration of $\mathrm{MeHg}$ at $80 \mathrm{~cm}$ above the sediment/water interface, which was oxic in July and became anoxic in September, and the occurrence of active methylation. They propose two possible explanations for this finding: 1) diffusion from the epilimnetic sediment via particles that resettle in other parts of the lake, and 2) methylation in the anoxic portion of the water column. The second hypothesis is consistent with the work of Rosati et al. (2018) in the permanent anoxic layer of the Black Sea. These authors conclude from their findings that in water bodies where oxygen depletion or absence at the bottom of the water column is induced by summer stratification, hypoxia-anoxia conditions could enhance $\mathrm{MeHg}$ production over areas much larger than originally thought, producing a significant amount of $\mathrm{MeHg}$.

Despite some contradictory evidence regarding the importance of the ODZ in $\mathrm{Hg}$ methylation along marine water columns, POC mineralization appears to be a driving factor regulating $\mathrm{MeHg}$ production in the water column. POC, especially sinking particles, has been the leading candidate in determining the microenvironment in which $\mathrm{Hg}$ methylation takes place in the water column.

\section{Evidence from microenvironment observations}

In order for the settling particles to sustain $\mathrm{Hg}$ methylation, there is the need for an anoxic microenvironment inside the particle or the entire particle to be anoxic. In both cases, an Eh gradient should exist between the particle and external environment (i.e., the water column) resulting from the different redox conditions.
Alldredge and Cohen (1987) found a persistent oxygen and $\mathrm{pH}$ gradient in the microenvironment around marine snow. They used a calibrated oxygen microelectrode with a sensing tip of $2.5 \mu \mathrm{m}$ on particles ranging from 1 to $4 \mathrm{~mm}$. The oxygen was partially, but continuously, depleted within and around marine snow in the dark and at times completely depleted within large fecal pellets, creating anoxic microenvironments at the core of these particles where oxygen-free related processes could occur. Moreover, Glud et al. (2015) found evidence of existing anoxic microenvironments with high microbial activity inside copepod carcasses. Even in oxygen-saturated water, carcasses of Calanus finmarchicus had an anoxic interior that gradually expanded with decreasing ambient $\mathrm{O}_{2}$ levels. Following this evidence, Ortiz et al. (2015) designed an experiment in which marine settling particles were produced in a controlled microcosm using sieved estuarine sediment. The size of these particles was heterogeneous and spanned $0.2 \mu \mathrm{m}$ to $>300 \mu \mathrm{m}$. Using isotopically enriched $\mathrm{Hg}$ spikes, these authors measured the Hg methylation rates comparable to those measured in sediments, highlighting the possibility of methylation in marine snow and small particles in open ocean and coastal waters.

In a previous study in Lake Constance, Grossart and Simon (1993) studied the macroaggregates - named lake snow - and showed the similarities and differences between this and its marine equivalent. In terms of its abundance, chemical composition, settling velocity, microbial colonization, and bacterial production, lake snow is fairly similar to marine snow. In contrast, the formation of lake snow aggregates is mostly dependent on wind induced turbulences and presents differences in particle composition because of the differences between marine and freshwater plankton communities. Regardless, all of these results show that lake snow, similar to marine snow, represents an important site for OM mineralization, nutrient regeneration, and, potentially, $\mathrm{Hg}$ methylation.

As discussed above, settling particles are of great importance in the aquatic environment. Inputs of new particulate material via rivers, the resuspension of sediments from the lake (or sea) basin, and contributions originating from the in situ production of fresh OM from plants, algae, phyto- and zooplankton, and inorganic particles (silica from diatom frustules and carbonates from precipitation in hard water lakes) represent the main source of settling particles in aquatic environments (Gardner et al., 1985; Blais and Kalff, 1995). The presence of micro- and macroaggregates in the water column plays an important role in the cycles of nutrients and pollutants (Grossart and Simon, 1993; Wieland et al., 2001; Ortiz et al., 2015), owing to the mainly organic composition and high concentration of bacteria in these particles (Grossart and Simon, 1993; Simon et al., 2002).

All of these studies suggest the presence of a source 
of $\mathrm{MeHg}$ aside from sediment in freshwater/estuarine environments. Presently, there is no direct observation of $\mathrm{Hg}$ methylation in the settling particles in a lake water column. However, Gascón Díez et al. (2016), via sediment traps in Lake Geneva, found high $\mathrm{MeHg}$ concentrations in settling particles, likely as a result of SRB methylation activity within the oxic water column.

\section{Evidence from biota}

Finally, indirect evidence of the possible role of methylation within the water column include studies in freshwater environments highlighting the unrelated concentrations of $\mathrm{MeHg}$ in lake biota compared to the concentrations in sediment. Hammerschmidt and Fitzgerald (2006) compared a large dataset of $\mathrm{MeHg}$ concentrations in fish across the US. They found a weak correlation between $\mathrm{MeHg}$ in fish and parameters such as surface water $\mathrm{pH}$, temperature, and wet atmospheric precipitations of sulfate; however, the levels of atmospheric $\mathrm{Hg}$ account for about two-thirds of the $\mathrm{MeHg}$ variation in fish. Moreover, Zhou et al. (2017) found declining temporal trends in $\mathrm{MeHg}$ concentrations in top predator fish in several US lakes from 2004 to 2015. Those trends were related to a decreasing regional atmospheric $\mathrm{Hg}$ emission rather than a lower concentration of $\mathrm{MeHg}$ in the sediment. Hodson et al. (2014) found the highest $\mathrm{MeHg}$ concentrations in biota near the Canadian Saint Francis Lake tributaries and not near the most contaminated industrial site, suggesting that legacy $\mathrm{Hg}$ in surficial sediments is not bioavailable to aquatic biota.

Other important evidence was collected in both marine and freshwater environments in studies on the base of the trophic chain (i.e., phyto and zooplankton), coupling $\mathrm{MeHg}$ concentrations with parameters such as feeding ecology, size, species, etc. Kainz and Mazumder (2005) studied the zooplankton efficiency in retaining $\mathrm{MeHg}$ in several lakes on Vancouver Island, Canada. Using dietary lipid biomarkers, they found that $\mathrm{MeHg}$ concentrations were not significantly related to zooplankton taxonomy, but did have a strong direct correlation with zooplankton size. Their results suggest that macrozooplankton $(>500$ $\mu \mathrm{m})$, the preferred size for planktivorous fish, are the most efficient at retaining and accumulating $\mathrm{MeHg}$, and eventually incorporating it into the trophic chain.

Chiang et al. (2021) studied bio-magnification of $\mathrm{MeHg}$ in coastal food webs of Patagonian fjords and Antarctic Peninsula. They found that nearshore food webs show an increased $\mathrm{MeHg}$ bio-magnification compared to the off-shore ones. They conclude that this is probably due to the supply of freshwater that increases the bioavailability of $\mathrm{Hg}$ for the base of the food web.

Wu et al. (2019a) reviewed several works from different aquatic ecosystem on the bio-concentration and the bio-magnification of $\mathrm{MeHg}$ at the base of the food chain (phyto and zoo-plankton), to determine which process better predicts $\mathrm{MeHg}$ concentration in fish. They found that bio-concentration of $\mathrm{MeHg}$ in phytoplankton predicts $63 \%$ of the variability of $\mathrm{MeHg}$ concentrations in fish, while zooplanktivory diet did not appear to have a significant correlation with $\mathrm{MeHg}$ in fish.

Phytoplankton represents the entry point of $\mathrm{Hg}$ species into the food chain because of its faculty to scavenge $\mathrm{Hg}$ from the subsurface waters and transfer it deeper by settling after the cell death. Pickhardt and Fisher (2007) used ${ }^{203} \mathrm{Hg}$ to compare inorganic $\mathrm{Hg}$ and $\mathrm{MeHg}$ uptake in five phytoplankton species (three eukaryotic and two prokaryotic) in two water bodies characterized by low and high dissolved organic carbon (DOC). For MeHg, they found volume concentrations 2 to 2.6 times higher in high DOC water than in low DOC water for eukaryotic cells, while the concentrations were similar in prokaryote cells. This increase can be explained by a difference in the $\mathrm{Hg}$ speciation between high and low DOC; the authors suggest that due to the greater abundance of the lipid-soluble, neutral methylmercury chloride complex $\mathrm{CH}_{3} \mathrm{HgCl}$ in high DOC waters, $\mathrm{MeHg}$ uptake could be enhanced. They also found a positive correlation between $\mathrm{MeHg}$ concentrations and the ratio of the surface area over volume of the cell, a correlation that is not present with inorganic mercury.

These results are consistent with the work of Zhang et al. (2020) who developed a global 3D simulation of $\mathrm{MeHg}$ in seawater and phyto and zooplankton based on the Massachusetts Institute of Technology global circulation model. Their model suggests that diatoms and Synechococcus spp. (a picocyanobacteria) are the most important phytoplankton categories for the transfer of $\mathrm{MeHg}$ from seawater to herbivorous zooplankton, contributing $35 \%$ and $25 \%$, respectively.

Moreover, a dietary analysis was carried out by Wu et al. (2019b) using stable isotopes and fatty acids to assess the role of the food source in $\mathrm{Hg}$ and $\mathrm{MeHg}$ biomagnification in six Swedish lakes. They found that terrestrial and algae diets together predicted more than $66 \%$ of the $\mathrm{Hg}$ variability in meso zooplankton $(100-500 \mu \mathrm{m})$ and macro-zooplankton $(>500 \mu \mathrm{m})$. Additionally, physicochemical parameters like $\mathrm{pH}$ and DOC were also correlated with $\mathrm{Hg}$ bioaccumulation, suggesting an influence of such parameters on mediating the impact of consuming different dietary sources.

Poste et al. (2019) conducted a comparative research between two contrasted boreal lakes in Norway characterized one by low amount of terrestrial OM (clear-water) and the other with high amount of terrestrial OM (brownwater). They determined zooplankton $\mathrm{MeHg}$ accumulation and dietary preferences in both lakes. They found that high amount of terrestrial OM results in high concentrations of $\mathrm{MeHg}$ in water and zooplankton and reduces zooplankton dietary dependence on phytoplankton. This in 
turn reduces the quality of zooplankton as a feeding source (i.e., high $\mathrm{MeHg}$ concentrations) with effects on all trophic levels.

Phytoplankton and zooplankton represent the first step in the pelagic trophic chain and are important vectors for $\mathrm{MeHg}$ biomagnification across the food web. The localization and characterization of their source of exposure to $\mathrm{MeHg}$ is an important step to understanding how $\mathrm{MeHg}$ enters the food web and is an essential information for every remediation project in a given environment.

\section{Conceptual model of the short path of the food chain}

The role of $\mathrm{Hg}$ methylation in settling particles in a limnic environment is schematized in Fig. 1. Microorganism colonies in settling particles will begin to methylate $\mathrm{Hg}$ thanks to the redox gradient present inside the particles and their prevalent organic composition. The two production sites, represented by sediment (brown) and settling particles (green), create two different entry points into the trophic chain for $\mathrm{MeHg}$, which in turn creates two different paths of $\mathrm{MeHg}$ biomagnification, represented in Fig. 1 by the short and long path.

The importance of the short path can be seen in marine environments where the greater depths make the transfer of $\mathrm{MeHg}$ from the sediment into the pelagic trophic chain less likely, making $\mathrm{MeHg}$ production from suspended and settling particles more important because it takes place where low-trophic-level biota, such as zooplankton, thrive, increasing their $\mathrm{MeHg}$ exposure and entering into the pelagic food web (Soerensen et al., 2018; Wang et al., 2018). While the bottom sediments of a shallow lake probably represent the main $\mathrm{MeHg}$ source of exposure for all the biota, a deep lake could behave similarly to an ocean in terms of separation between the long and short transfer paths, giving more importance to $\mathrm{Hg}$ methylation in the water column with respect to the exposure of biota. Nevertheless, several different site-specific variables must be taken into account to adjust this model. Depth can function as a separator between the pelagic short path and

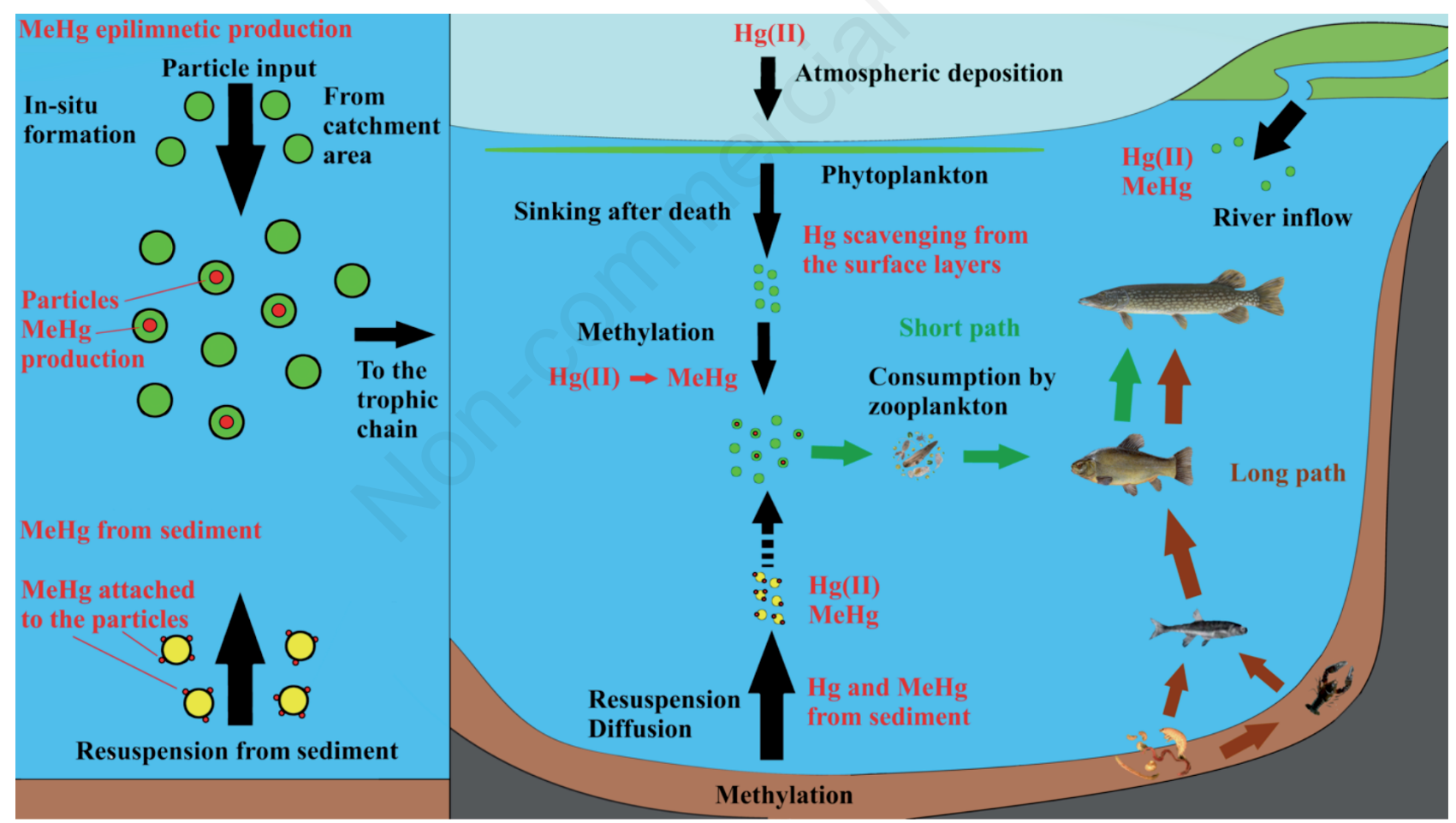

Fig. 1. Schematic summary of the role of suspended particles for $\mathrm{Hg}$ incorporation into the food chain in a freshwater environment. Settling particles (green circles) produce $\mathrm{MeHg}$ (red dots) at a shallower depth in respect to the classic source in the bottom sediments (brown), determining two different transfer paths in the trophic chain: short (green) and long (dark brown) paths. On the left, the epilimnetic production zone (settling particles) is represented in detail. Resuspended particles (yellow circles) can transport MeHg from the bottom sediment zone of methylation to the epilimnetic one, making it very difficult to quantify the relative importance of the two sources. However, the deeper a water body is, the less important becomes the effect of the sediment resuspension due to distance between the primary production zone to the bottom sediments, so depth can play a major role in separating these two sources of MeHg. Moreover, depth could affect the amount of $\mathrm{MeHg}$ that arrives into the surface layers from the long-path trophic chain, in turn giving more importance to epilimnetic methylation. 
the benthic long path, but sediment resuspension can transport $\mathrm{MeHg}$ produced in the bottom sediment to the upper layers of the lake via particles, mixing the $\mathrm{MeHg}$ contribution from epilimnetic production with that from the sediment (Fig. 1). This resuspension from the bottom sediment can occur following several dynamics, the presence and effectiveness of which are site-specific: wind, tributaries, and density currents. Moreover, biotic and abiotic demethylation inside and around resuspended particles could occur, reducing the amount of $\mathrm{MeHg}$ that reaches the epilimnetic production zone. Finally, photoreduction of $\mathrm{Hg}$ to volatile $\mathrm{Hg}^{0}$ is an important reaction in removing bioavailable $\mathrm{Hg}$ before it reaches the $\mathrm{MeHg}$ production microenvironments. In natural waters, $\mathrm{Hg}$ photoreduction is known to increase with increasing content of DOC (Costa and Liss, 1999). This trend peaks at a $\mathrm{Hg} / \mathrm{DOC}$ ratio of $1134 \mathrm{ng} \mathrm{mg}^{-1}$, according to Wang et al. (2020), corresponding to the maximum photoreduction rate; further increase or decrease of this ratio will in turn decrease the $\mathrm{Hg}$ reduction rate. Studies on these dynamics and how they affect the system are needed to determine the relative importance between the short and long path in a given environment.

\section{SUMMARY AND PERSPECTIVES}

This review highlights the oxic water column as another important site of $\mathrm{MeHg}$ production in deep lakes. The presence of settling particles in aquatic systems (lake and marine snow) is the key factor which permits $\mathrm{Hg}$ methylation in an environment otherwise incompatible with anoxic bacterial activity. The microenvironments that form around and inside these micro- and macroaggregates, coupled with their composition rich in OM, create the perfect substrate for methylators to proliferate.

The existence of a source of MeHg inside the ecosystem in which the majority of macroinvertebrates and fish live is of great importance and should be further investigated and elucidated. While marine environments present a large and increasing literature on the subject, the same cannot be said of freshwater systems.

To address this knowledge gap, it is of great importance to identify and standardize sampling and analysis setups to create comparable data about $\mathrm{THg}$ and $\mathrm{MeHg}$ concentrations. Specifically, there is a need to design a sampling setup capable of recovering suspended and settling particles without creating any unwanted effects (e.g., change in redox conditions, increased temperature) that could interfere with the actual MeHg concentrations. An ideal sampling setup should consist of a system capable of sampling particles from the water column (e.g., an in situ pump) and quickly transfer them onto a collecting device on which the particles can accumulate (e.g., filters). Afterward, the sample must be stored (possibly frozen to block biotic processes) and freeze-dried as soon as possible. In order to facilitate analysis, a colleting device from which the particles can be isolated could be very useful. Moreover, the collected samples should be used to determine the presence of the gene cluster $h g c A B$ and to identify the microbial community present in the samples through shotgun or high-throughput sequencing metagenomics. Once the analytical setup has been identified, it should be applied to different systems in order to obtain a set of relevant data needed to elucidate this step in $\mathrm{Hg}$ cycling in the aquatic environment. Another knowledge gap that needs to be addressed is the quantification of the $\mathrm{MeHg}$ flux that goes from settling particles to lowtrophic-level biota (e.g., zooplankton). This step is of major importance to quantify the real threat of this pelagic source of $\mathrm{MeHg}$ and to assess biomagnification rates. This could be realized in a macrocosm experiment with isotopic tracers to track $\mathrm{MeHg}$ inside various biota species.

\section{ACKNOWLEDGMENTS}

We would like to thank Editage (www.editage.com) for the English-language editing.

\section{REFERENCES}

Alldredge AL, Cohen Y, 1987. Can Microscale chemical patches persist in the sea? Microelectrode study of marine snow, fecal pellets. Science 235:689-691.

Amap/UNEP, 2013. Technical background report for the Global Mercury Assessment 2013. Arctic Monitoring and Assessment Programme, Oslo, Norway/UNEP Chemicals Branch, Geneva, Switzerland.

Amap/UNEP, 2015. Global mercury modelling: Update of modelling results in the global mercury assessment 2013. Arctic Monitoring and Assessment Programme, Oslo, Norway/UNEP Chemicals Branch, Geneva, Switzerland.

Benoit JM, Gilmour CC, Heyes A, Mason RP, Miller CL, 2003. Geochemical and biological controls over methylmercury production and degradation in aquatic ecosystems, p. 262297. In: Y. Cai and O.C. Braids (eds.), Biogeochemistry of environmentally important trace elements. Washington, DC: American Chemical Society.

Bianchi D, Weber TS, Kiko R, Deutsch C, 2018. Global niche of marine anaerobic metabolisms expanded by particle microenvironments. Nat. Geosci. 11:263-268.

Blais JM, Kalff J, 1995. The influence of lake morphometry on sediment focusing. Limnol. Oceanogr. 40:582-588.

Blum JD, Popp BN, Drazen JC, Anela Choy C, Johnson MW, 2013. Methylmercury production below the mixed layer in the North Pacific Ocean. Nat. Geosci. 6:879-884.

Bowman KL, Collins RE, Agather AM, Lamborg CH, Hammerschmidt CR, Kaul D, Dupont CL, Christensen GA, Elias DA, 2019. Distribution of mercury-cycling genes in the Arctic and equatorial Pacific Oceans and their relationship to mercury speciation. Limnol. Oceanogr. 65:S310-320. 
Bowman KL, Hammerschmidt CR, Lamborg CH, Swarr G, 2015. Mercury in the North Atlantic Ocean: The U.S. GEOTRACES zonal and meridional sections. Deep-Sea Res. Pt. II 116:251-261.

Bowman KL, Hammerschmidt CR, Lamborg CH, Swarr GJ, Agather AM, 2016. Distribution of mercury species across a zonal section of the eastern tropical South Pacific Ocean (U.S. GEOTRACES GP16). Mar. Chem. 186:156-166.

Bravo AG, Cosio C, 2019. Biotic formation of methylmercury: A bio-physico-chemical conundrum. Limnol. Oceanogr. 65:1010-1027.

Bravo AG, Zopfi J, Buck M, Xu J, Bertilsson S, Schaefer JK, Poté J, Cosio C, 2018. Geobacteraceae are important members of mercury-methylating microbial communities of sediments impacted by waste water releases. ISME J. 12:802-812.

Chiang G, Kidd KA, Díaz-Jaramillo M, Espejo W, Bahamonde P, O'driscoll NJ, Munkittrick KR, 2021. Methylmercury biomagnification in coastal aquatic food webs from western Patagonia and western Antarctic Peninsula. Chemosphere 262:128360.

Christensen GA, Gionfriddo CM, King AJ, Moberly JG, Miller CL, Somenahally AC, Callister SJ, Brewer H, Podar M, Brown SD, Palumbo AV, Brandt CC, Wymore AM, Brooks SC, Hwang C, Fields MW, Wall JD, Gilmour CC, Elias DA, 2019. Determining the reliability of measuring mercury cycling gene abundance with correlations with mercury and methylmercury concentrations. Environ. Sci. Technol. 53:8649-8663.

Compeau GC, Bartha R, 1985. Sulfate-reducing bacteria: Principal methylators of mercury in anoxic estuarine sedimentt. Appl. Environ. Microbiol. 50:498-501.

Correia RRS, Guimarães JRD, 2017. Mercury methylation and sulfate reduction rates in mangrove sediments, Rio de Janeiro, Brazil: The role of different microorganism consortia. Chemosphere 167:438-443.

Cossa D, Averty B, Pirrone N, 2009. The origin of methylmercury in open Mediterranean waters. Limnol. Oceanogr. 54:837-844.

Cossa D, Durrieu De Madron X, Schäfer J, Lanceleur L, Guédron S, Buscail R, Thomas B, Castelle S, Naudin J-J, 2017. The open sea as the main source of methylmercury in the water column of the Gulf of Lions (Northwestern Mediterranean margin). Geochim. Cosmochim. Acta 199:222-237.

Cossa D, Heimbürger L-E, Lannuzel D, Rintoul SR, Butler ECV, Bowie AR, Averty B, Watson RJ, Remenyi T, 2011. Mercury in the Southern Ocean. Geochim. Cosmochim. Acta 75:4037-4052.

Cossa D, Heimbürger L-E, Pérez FF, García-Ibáñez MI, Sonke JE, Planquette H, Lherminier P, Boutorh J, Cheize M, Menzel Barraqueta JL, Shelley R, Sarthou G, 2018. Mercury distribution and transport in the North Atlantic Ocean along the GEOTRACES-GA01 transect. Biogeosciences 15:2309-2323.

Costa M, Liss PS, 1999. Photoreduction of mercury in sea water and its possible implications for $\mathrm{Hg} 0$ air-sea fluxes. Mar. Chem. 68:87-95.

Du H, Ma M, Igarashi Y, Wang D, 2019. Biotic and abiotic degradation of methylmercury in aquatic ecosystems: A review. Bull. Environ. Contam. Toxicol. 102:605-611.

Eckley CS, Hintelmann H, 2006. Determination of mercury methylation potentials in the water column of lakes across Canada. Sci. Total Environ. 368:111-125.

FAO, 2018. The State of World Fisheries and Aquaculture 2018. Meeting the sustainable development goals. Available from: http://www.fao.org/documents/card/en/c/I9540EN/

Fitzgerald WF, Lamborg CH, 2014. Geochemistry of mercury in the environment, p. 91-129. In: H.D. Holland and K.K. Turekian (eds.), Treatise on geochemistry, second Edition. Oxford, Elsevier.

Fleming EJ, Mack EE, Green PG, Nelson DC, 2006. Mercury methylation from unexpected sources: Molybdate-Inhibited freshwater sediments and an iron-reducing bacterium. Appl. Environ. Microbiol. 72:457-464.

Gardner WD, Southard JB, Hollister CD, 1985. Sedimentation, resuspension and chemistry of particles in the northwest Atlantic. Mar. Geol. 65:199-242.

Gascón Díez E, Loizeau J-L, Cosio C, Bouchet S, Adatte T, Amouroux D, Bravo AG, 2016. Role of settling particles on mercury methylation in the oxic water column of freshwater systems. Environ. Sci. Technol. 50:11672-11679.

Gilmour CC, Podar M, Bullock AL, Graham AM, Brown SD, Somenahally AC, Johs A, Hurt RA, Bailey KL, Elias DA, 2013. Mercury methylation by novel microorganisms from new environments. Environ. Sci. Technol. 47:11810-11820.

Gionfriddo CM, Tate MT, Wick RR, Schultz MB, Zemla A, Thelen MP, Schofield R, Krabbenhoft DP, Holt KE, Moreau JW, 2016. Microbial mercury methylation in Antarctic sea ice. Nat. Microbiol. 1:16127.

Glud RN, Grossart H-P, Larsen M, Tang KW, Arendt KE, Rysgaard S, Thamdrup B, Gissel Nielsen T, 2015. Copepod carcasses as microbial hot spots for pelagic denitrification: Copepod carcasses and denitrification. Limnol. Oceanogr. 60:2026-2036.

Grossart H-P, Simon M, 1993. Limnetic macroscopic organic aggregates (lake snow): Occurrence, characteristics, and microbial dynamics in Lake Constance. Limnol. Oceanogr. 38:532-546.

Hammerschmidt CR, Fitzgerald WF, 2006. Methylmercury in freshwater fish linked to atmospheric mercury deposition. Environ. Sci. Technol. 40:7764-7770.

Hodson PV, Norris K, Berquist M, Campbell LM, Ridal JJ, 2014. Mercury concentrations in amphipods and fish of the Saint Lawrence River (Canada) are unrelated to concentrations of legacy mercury in sediments. Sci. Total Environ. 494-495:218-228.

Kainz M, Mazumder A, 2005. Effect of algal and bacterial diet on methyl mercury concentrations in zooplankton. Environ. Sci. Technol. 39:1666-1672.

Kim H, Soerensen AL, Hur J, Heimbürger L-E, Hahm D, Rhee TS, Noh S, Han S, 2017. Methylmercury mass budgets and distribution characteristics in the Western Pacific Ocean. Environ. Sci. Technol. 51:1186-1194.

King JK, Kostka JE, Frisher ME, Saunders FM, 2000. Sulfatereducing bacteria methylate mercury at variable rates in pure culture and in marine sediments. Appl. Environ. Microbiol. 66:2430-2437.

Kirk JL, St. Louis VL, Hintelmann H, Lehnherr I, Else B, Poissant L, 2008. Methylated mercury species in marine waters of the Canadian High and Sub Arctic. Environ. Sci. Technol. 42:8367-8373. 
Lamborg CH, Hammerschmidt CR, Bowman KL, 2016. An examination of the role of particles in oceanic mercury cycling. Philos. T. R. Soc. A 374:20150297.

Lamborg CH, Yiğiterhan O, Fitzgerald WF, Balcom PH, Hammerschmidt CR, Murray J, 2008. Vertical distribution of mercury species at two sites in the Western Black Sea. Mar. Chem. 111:77-89.

Lehnherr I, St. Louis VL, Hintelmann H, Kirk JL, 2011. Methylation of inorganic mercury in polar marine waters. Nature Geosci. 4:298-302.

Lu X, Gu W, Zhao L, Haque MFU, Dispirito AA, Semrau JD, $\mathrm{Gu}$ B, 2017. Methylmercury uptake and degradation by methanotrophs. Sci. Adv. 3:e1700041.

Lu X, Liu Y, Johs A, Zhao L, Wang T, Yang Z, Lin H, Elias DA, Pierce EM, Liang L, Barkay T, Gu B, 2016. Anaerobic Mercury Methylation and Demethylation by Geobacter bemidjiensis Bem. Environ. Sci. Technol. 50:4366-4373.

Malcolm EG, Schaefer JK, Ekstrom EB, Tuit CB, Jayakumar A, Park H, Ward BB, Morel FMM, 2010. Mercury methylation in oxygen deficient zones of the oceans: No evidence for the predominance of anaerobes. Mar. Chem. 122:11-19.

Mason RP, Fitzgerald WF, 1990. Alkylmercury species in the equatorial Pacific. Nature 347:457-459.

Mason RP, Fitzgerald WF, 1993. The distribution and biogeochemical cycling of mercury in the equatorial Pacific Ocean. Deep-Sea Res. Pt. I 40:1897-1924.

Matilainen T, Verta M, 1995. Mercury methylation and demethylation in aerobic surface waters. Can. J. Fish. Aquat. Sci. 52:1597-1608.

Monperrus M, Tessier E, Amouroux D, Leynaert A, Huonnic P, Donard OFX, 2007a. Mercury methylation, demethylation and reduction rates in coastal and marine surface waters of the Mediterranean Sea. Mar. Chem. 107:49-63.

Monperrus M, Tessier E, Point D, Vidimova K, Amouroux D, Guyoneaud R, Leynaert A, Grall J, Chauvaud L, Thouzeau G, Donard OFX, 2007b. The biogeochemistry of mercury at the sediment-water interface in the Thau Lagoon. 2. Evaluation of mercury methylation potential in both surface sediment and the water column. Estuar. Coast. Shelf Sci 72:485-496.

Munson KM, Lamborg CH, Boiteau RM, Saito MA, 2018. Dynamic mercury methylation and demethylation in oligotrophic marine water. Biogeosciences 15:6451-6460.

Nascimento AMA, Chartone-Souza E, 2003. Operon mer: Bacterial resistance to mercury and potential for bioremediation of contaminated environments. Genet. Mol. Res. 2:92-101.

Ortiz VL, Mason RP, Evan Ward J, 2015. An examination of the factors influencing mercury and methylmercury particulate distributions, methylation and demethylation rates in laboratory-generated marine snow. Mar. Chem. 177:753-762.

Pak K-R, Bartha R, 1998. Mercury methylation and demethylation in anoxic lake sediments and by strictly anaerobic bacteria. Appl Environ Microbiol. 64:1013-1017.

Paranjape AR, Hall BD, 2017. Recent advances in the study of mercury methylation in aquatic systems. Facets 2:85-119.

Parks JM, Johs A, Podar M, Bridou R, Hurt RA, Smith SD, Tomanicek SJ, Qian Y, Brown SD, Brandt CC, Palumbo AV, Smith JC, Wall JD, Elias DA, Liang L, 2013. The genetic basis for bacterial mercury methylation. Science 339:13321335 .
Peterson BD, Mcdaniel EA, Schmidt AG, Lepak RF, Janssen SE, Tran PQ, Marick RA, Ogorek JM, Dewild JF, Krabbenhoft DP, Mcmahon KD, 2020. Mercury methylation genes identified across diverse anaerobic microbial guilds in a eutrophic sulfate-enriched lake. Environ. Sci. Technol. 54:15840-15851.

Pickhardt PC, Fisher NS, 2007. Accumulation of inorganic and methylmercury by freshwater phytoplankton in two contrasting water bodies. Environ. Sci. Technol. 41:125-131.

Podar M, Gilmour CC, Brandt CC, Soren A, Brown SD, Crable BR, Palumbo AV, Somenahally AC, Elias DA, 2015. Global prevalence and distribution of genes and microorganisms involved in mercury methylation. Sci. Adv. 1:e1500675e1500675.

Poste AE, Skaar Hoel C, Andersen T, Arts MT, Færøvig P-J, Borgå K, 2019. Terrestrial organic matter increases zooplankton methylmercury accumulation in a brown-water boreal lake. Sci. Total Environ 674:9-18.

Qian C, Chen H, Johs A, Lu X, An J, Pierce EM, Parks JM, Elias DA, Hettich RL, Gu B, 2018. Quantitative proteomic analysis of biological processes and responses of the bacterium Desulfovibrio desulfuricans ND132 upon deletion of its mercury methylation genes. Proteomics 18:1700479.

Regnell O, Watras CJ, 2019. Microbial mercury methylation in aquatic environments: A critical review of published field and laboratory studies. Environ. Sci. Technol. 53:4-19.

Rosati G, Heimbürger LE, Melaku Canu D, Lagane C, Laffont L, Rijkenberg MJA, Gerringa LJA, Solidoro C, Gencarelli CN, Hedgecock IM, De Baar HJW, Sonke JE, 2018. Mercury in the Black Sea: New insights from measurements and numerical modeling. Global Biogeochem. Cycles 32:529550.

Schaefer JK, Rocks SS, Zheng W, Liang L, Gu B, Morel FMM, 2011. Active transport, substrate specificity, and methylation of $\mathrm{Hg}(\mathrm{II})$ in anaerobic bacteria. P. Natl. Acad. Sci. USA 108:8714-8719.

Selin NE, 2014. Global change and mercury cycling: Challenges for implementing a global mercury treaty: Global change and mercury cycling. Environ. Toxicol. Chem. 33:12021210.

Si Y, Zou Y, Liu X, Si X, Mao J, 2015. Mercury methylation coupled to iron reduction by dissimilatory iron-reducing bacteria. Chemosphere 122:206-212.

Simon M, Grossart H, Schweitzer B, Ploug H, 2002. Microbial ecology of organic aggregates in aquatic ecosystems. Aquat. Microb. Ecol. 28:175-211.

Soerensen AL, Schartup AT, Skrobonja A, Bouchet S, Amouroux D, Liem-Nguyen V, Björn E, 2018. Deciphering the Role of water column redoxclines on methylmercury cycling using speciation modeling and observations from the Baltic Sea. Glob. Biogeochem. Cycles 32:1498-1513.

Sunderland EM, Krabbenhoft DP, Moreau JW, Strode SA, Landing WM, 2009. Mercury sources, distribution, and bioavailability in the North Pacific Ocean: Insights from data and modelsn. Global Biogeochem. Cycles 23:GB2010.

Sunderland EM, Selin NE, 2013. Future trends in environmental mercury concentrations: implications for prevention strategies. Environ. Health 12:2.

Topping G, Davies IM, 1981. Methylmercury production in the marine water column. Nature 290:243-244. 
Ullrich SM, Tanton TW, Abdrashitova SA, 2001. Mercury in the aquatic environment: A review of factors affecting methylation. Crit. Rev. Environ. Sci. Technol. 31:241-293.

Villar E, Cabrol L, Heimbürger-Boavida L-E, 2020. Widespread microbial mercury methylation genes in the global ocean. Environ Microbiol Rep. 12:277-287.

Wang F, Macdonald RW, Armstrong DA, Stern GA, 2012. Total and methylated mercury in the Beaufort Sea: The role of local and recent organic remineralization. Environ. Sci. Technol. 46:11821-11828.

Wang F, Outridge PM, Feng X, Meng B, Heimbürger-Boavida L-E, Mason RP, 2019. How closely do mercury trends in fish and other aquatic wildlife track those in the atmosphere? - Implications for evaluating the effectiveness of the Minamata Convention. Sci. Total Environ. 674:58-70.

Wang K, Munson KM, Beaupré-Laperrière A, Mucci A, Macdonald RW, Wang F, 2018. Subsurface seawater methylmercury maximum explains biotic mercury concentrations in the Canadian Arctic. Sci. Rep. 8:14465.

Wang Z, Fei Z, Wu Q, Yin R, 2020. Evaluation of the effects of $\mathrm{Hg} / \mathrm{DOC}$ ratios on the reduction of $\mathrm{Hg}$ (II) in lake water. Chemosphere 253:126634.

Wieland E, Lienemann P, Bollhalder S, Lück A, Santschi PH, 2001. Composition and transport of settling particles in Lake
Zurich: relative importance of vertical and lateral pathways. Aquat. Sci. 63:123-149.

Wu P, Kainz MJ, Åkerblom S, Bravo AG, Sonesten L, Branfireun B, Deininger A, Bergström A-K, Bishop K, 2019a. Terrestrial diet influences mercury bioaccumulation in zooplankton and macroinvertebrates in lakes with differing dissolved organic carbon concentrations. Sci. Total Environ 669:821-832.

Wu P, Kainz MJ, Bravo AG, Åkerblom S, Sonesten L, Bishop $\mathrm{K}, 2019 \mathrm{~b}$. The importance of bioconcentration into the pelagic food web base for methylmercury biomagnification: A meta-analysis. Sci. Total Environ. 646:357-367.

Zhang L, Planas D, 1994. Biotic and abiotic mercury methylation and demethylation in sediments. Bull. Environ. Contam. Toxicol. 52:691-698.

Zhang Y, Soerensen AL, Schartup AT, Sunderland EM, 2020. A global model for methylmercury formation and uptake at the base of marine food webs. Global Biogeochem. Cycles 34:e2019GB006348.

Zhou C, Cohen MD, Crimmins BA, Zhou H, Johnson TA, Hopke PK, Holsen TM, 2017. Mercury Temporal trends in top predator fish of the Laurentian Great Lakes from 2004 to 2015: Are concentrations still decreasing? Environ. Sci. Technol. 51:7386-7394. 